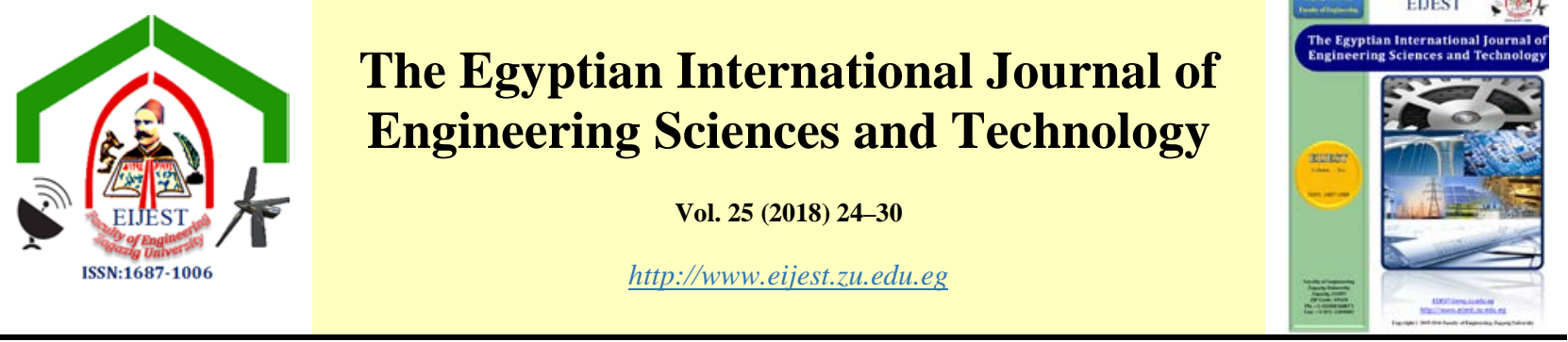

\title{
India’s New Architects
}

\author{
Areeg Alwaleed Abd Al-Hakam Al-Adel*
}

\begin{tabular}{l}
\hline A R T I C L E I N F O \\
\hline Article history: \\
Received 19 September \\
2017 \\
Received in revised form \\
30 March 2018 \\
Accepted 31 March 2018 \\
Available online 28 October \\
2018 \\
\hline
\end{tabular}

\section{Keywords:}

Architecture

Education

Architectural Education.

Architecture departement - Cairo University,Cairo - Nasr City11817, P.O Box:8, Egypt

\section{A B S T R A C T}

When it comes to construction, societies turn to architectural engineers for problem-solving. However, certain communities, due to their poverty, cannot afford the cost of the modern process of design and construction which leads to the appearance of random unplanned areas with designs and buildings that aggravate their problems instead of solving them. The people of Tilonia, India - an extremely poor community - have found a creative solution that does not complicate the problem even more. The solution lied in "creating" their own architects from within the community with a slight help from outside at first. They were called "Barefoot architects”.

This constitutes the subject of the present research paper that studies this model. First we'll observe and analyze all its aspects. Second, we'll determine its positives and negatives in order to benefit from it on a larger scale so that it would be of use to a greater number of poor communities that need such inventive solutions.

Previous researches studied this issue from different point of view: Hassan Fathy covered methods of building for poor people in his book 'Architecture for the Poor', others like Amr Abd Alghany - Ain Shams university, Masters thesis - was concerned with the Educational problems and solving them on the basis of comparison with other educational systems. Johan van Lengen studied the 'Barefoot' example as a greener approach to housing.

\section{Introduction}

The term "barefoot" was first used to refer to "barefoot doctors" who were Chinese villagers trained to handle the basic health needs of fellowvillage residents during the 1960s. According to Jolan van Lengen, the phrase "Barefoot Architect" was inspired by the first architects living in the distant past who mixed adobe by treading mud with their bare feet. [1] So, the term 'Barefoot' originated in China to describe rural health workers. It is a description of the Social Work and Research Centre's
(SWRC) - which is an organization that helps poor people. As in China, Tilonia's first Barefoot professionals' were villagers who worked in the health sector. Then emerged a group of 'Barefoot teachers, then a crafts section that aimed at increasing the income of craftspeople and migrant workers by selling in contemporary markets. That was part of the barefoot objectives in the early years [2].

The paper consists of three parts: an introduction that presents the subject of this research and explains its main concept; a body that shows its different aspects through observing and analyzing the model; then a

* Corresponding author. Tel.: +2-01005080735.

E-mail address: areeg.aladel@yahoo.com 
conclusion that includes the positives and negatives from the researcher's point of view leading to the results and recommendations

\section{Observing and analyzing the model}

As the paper is a case study, the first part of it is analyzing the Barefoot Architects model starting with the concept and history, then the Vision, Mission and Values, then the Curriculum and Architecture, and ending with the architectural projects: college campus, homes for the homeless and rain harvesting.

\subsection{A different concept of architectural education}

Barefoot College differentiates between two main important things: 'literacy' which is everything that an individual acquires in school and 'education' which is what the individual gains elsewhere in his environment - even the personal experiences. For that reason, the College considers everyone as an education resource [3].

The College has successfully demonstrated that it is possible to combine traditional knowledge and modern skills when the tools are available for common people whom we call 'barefoot'.

"The 'Barefoot approach" maybe considered as a concept that solves many educational problems.

\subsection{History}

In the late 60's a small group of determined educated young people started seeking alternative ways of dealing with poverty in the Indian countryside. In 1972, Meghraj from Tilonia and Bunker Roy - who was still a fresh graduate - started working on their dream of making rural culture a main source of knowledge as the formal one.

At first a group of professional geologists, economists, doctors, social workers and chartered accountants shared this dream with the villagers. Afterwards, the early 80's witnessed a major change; as the rural people were now in charge and the SWRC has changed to the 'Barefoot College' [2]

\subsection{College Building}

The campus extends over 8 acres; it consists of a number of eco-friendly dome-shaped buildings. They have soil floors and no chairs so that "poor students feel comfortable". [4] It is a model of self-sufficiency as it was designed to be completely solar powered. Moreover, the rooftops are used to harvest rainwater which is stored in underground tanks with a capacity of 500,000 litres. [5]

\subsection{Vision, Mission and Values}

The Barefoot College is a not-for-profit social enterprise working towards financial sustainability, largely through the delivery of its community based solar programs and its artisan industries. It is an Indian based international organisation, whose values are grounded in the life and approach of Mahatma Gandhi.

\subsubsection{Vision and Mission}

Bunker Roy [19], founder of the college, says "it is important to distinguish between literacy and education”. For example, an illiterate person could know how to cultivate different crops through the seasons so, "It would be a mistake to label this person as uneducated" Roy said. He thinks that acquiring any form of knowledge, no matter how it was gained, makes a person educated.

"The 'Barefoot' philosophy is based on a belief that one hundred years ago village communities thrived with no paper-qualified doctors, engineers, architects or teachers. Such communities developed their own knowledge, which has since been devalued”. [6]

\subsubsection{Values}

Skills and knowledge found in rural communities should be heard, respected and nurtured before looking for solutions that rely on outside experts.

- The SWRC management has been participatory. The participatory decision-making process was designed to implement the Barefoot College's six essential values: 1. Austerity, 2. Equality, 3. Collective Decision-Making, 4. Decentralization, 5. Self-Evaluation 6. Transparency and Accountability. [2]

- Barefoot College adopts the same philosophy in training members of the rural community to become educators in local schools. The objective is to decrease their dependency on external aid as well as to reduce migration by generating employment within the rural communities.

- The College gives little importance to urban 
experts with paper degrees because most of them do not have the necessary qualifications, i.e. patience, listening skills or humility, to respect traditional knowledge and skills and are unfit to live and work in remote areas. When the villagers were given the authority to solve their own problems, they gained in self-confidence, gender relations improved and a ripple effect of positive changes occurred.

- A central belief is that the knowledge, skills and wisdom found in villages should have the priority for its development over getting skills from outside.

- There are no leaders or superiors, only coordinators from the College who help facilitate the process. It is democratic, decentralized and participative problem-solving and decisionmaking. [7] This is one of the most important conditions for creativity.

- "The College believes that every teacher is a learner and that every learner is also a teacher."

"Learning by doing" is the adopted training philosophy in Barefoot College. "Practical demonstrations, "hands-on" experience and regular repetition help trainees”. [8] Figure 1

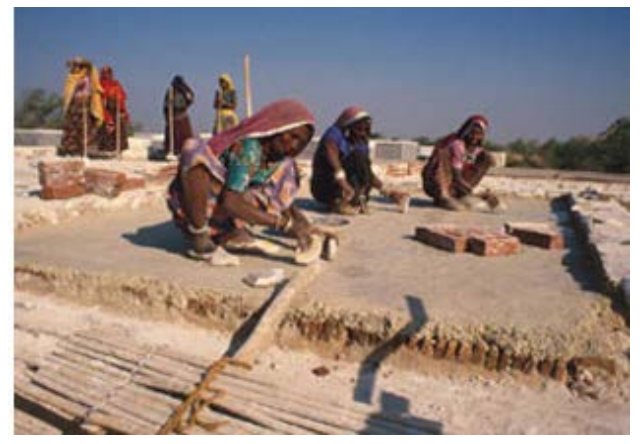

Figure 1: Learning by doing

Source:http://www.bruneions.com/educatio n-social/12033432-the-barefoot-movement

\subsection{Curriculum}

All programmes are designed to be taught using images and diagrams so that anyone can learn the same skills regardless of their age, gender or literacy. Courses are free and they usually last between six to nine months. [9]

Lessons are focused on fostering traditional skills that support sustainable living in rural communities. Literacy, as well, is considered important for holistic development. Teachers belong to the local community and receive rigorous training and ongoing support in their villages.

It is worth mentioning that the programmes have always distinguished between the capability to read and write, i.e. 'literacy', that children acquire in school, and the 'education' that they get from family, community, environment and personal experiences

\subsection{Architecture}

Hassan Fathy [20] proposed a form of partnership between the poor and the educated architects, where the poor have to put their labor and the architects solve the technical problems. [10] The same idea was applied in the Barefoot college as the architects found the technology of Buckminster Fulter's geodesic dome very useful and extensively applicable. Wood was sometimes used as a building material for constructing traditional houses in desert areas but this resource has become insufficient. Geodesic domes represented a good alternative as they are easily fabricated from scrap metal which is readily available from disused agricultural implements, tractors and pump sections. Figure 2. The structures are made to a span of 3 metres for small facilities such as dispensaries and telephone exchanges; 6 metres for small village classrooms and housing; or 10 metres for meeting halls accommodating up to one hundred people.

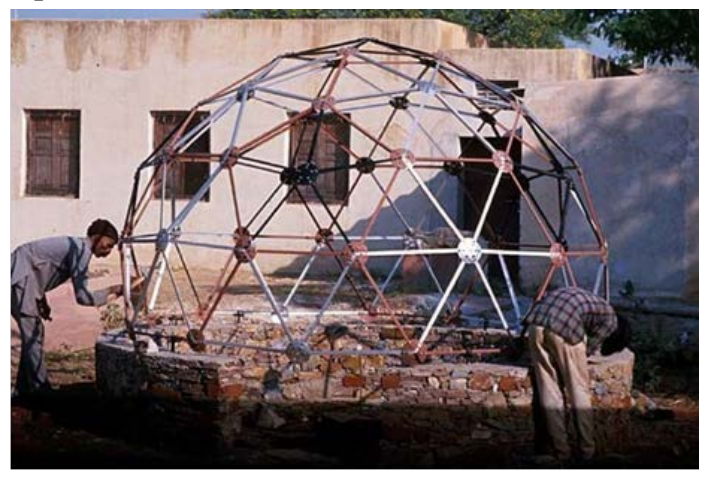

Figure 2: Geodesic dome technology Source:https://www.sfgate.com/homeandgarden/ article/Aga-Khan-Award-for-ArchitectureBuilding-2631518.php

Because of their structural capacities the domes can be covered with a greater weight of thatch than can traditional small-span structures reducing the frequency of rethatching. The use of geodesic dome technology also means that expertise now exists in 
the college for the construction of emergency structures and shelters, including relief housing. [11]

\subsection{Projects}

Barefoot architects, all belonging to the village community as we have mentioned earlier in this paper, have executed a number of projects that embodied the College ideals. The largest of these projects is the college campus itself "comprising a medical block, library/dining hall, amphitheater, guest house and residential blocks, craft centre, workshops and work-rooms, administrative buildings, and a few other isolated structures including geodesic domes housing various public facilities.”

'Homes for the Homeless' is another project that provided over two hundred basic residences in surrounding villages. That is why it is considered the most diffuse and wide-ranging programme.

"A rainwater-harvesting system has been developed to harvest rainwater from rooftops - a scheme that has provided scope for community involvement and control over the resource.” [11]

\subsubsection{First Project: Barefoot College Campus}

Since countrymen have been constructing their houses for generations without any consultation from urban architects, the College used the knowledge and skills that the locals already had to conceptualize and design the campus so it would be comfortable and appropriate to the rural staff. As nobody had had any formal training, there were no architectural drawings to consult for building. All plans of the campus were drawn over and over on the ground as the design evolved and changed. [12]

A traditional Indian courtyard design with surrounding verandas was chosen for most of the residential and administrative blocks. The buildings are cubic-shaped with flat roofs. Local materials, such as rubble stone with lime mortar, were used for load-bearing walls. According to Indian architectural tradition, the courtyards at ground level were highly decorated.

"The college is entirely solar powered and this contributes to its near self-sufficiency in terms of utility services.” [13] Figure 3

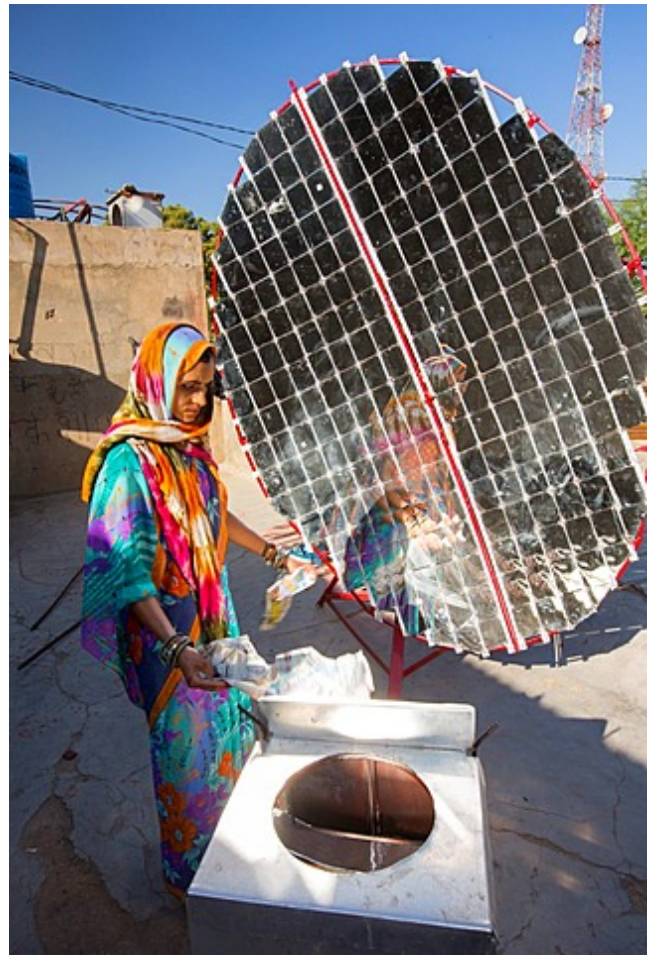

Figure 3: The college is Solar powered Source: http://www.alamy.com/stock-photo-womenconstructing-solar-cookers-at-the-barefoot-collegein-tilonia-65950541.html

The campus, built entirely by Barefoot architects, extends over 80,000 square feet area and includes many facilities as: a guest house, a library, a dining room, an open air theatre, a building for the administration, meeting halls, a ten-bed hospital, residences, teacher's training unit, a Post Office, a Craft Shop and Development Centre, an Internet café, a puppet workshop, an audio visual unit, water testing laboratory, and a 700,000 litre rainwater harvesting tank. The College also completely uses solar energy as a source of producing electricity and providing the energy that the place needs. [14]

The college and architects searched for a way to combine local labour and materials, as an opportunity to improve local skills and practices and to teach workers how to adapt new methods to available materials. For instance, it was easy to teach a local blacksmith the construction of geodesic domes from scrap metal. The success of this method is made clear through the construction of the college campus by an illiterate farmer from Tilonia, along with twelve Barefoot architects, most of which have no formal 
training. Several village women helped them working as labourers and carrying building materials. Figure 4

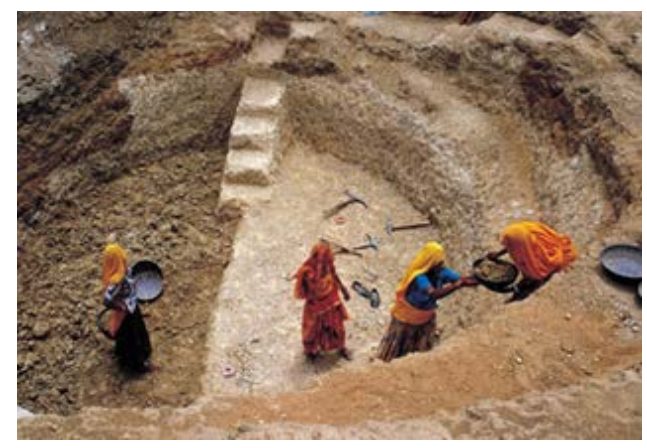

Figure 4: Women's Role

Source: http://www.bruneions.com/educationsocial/12033432-the-barefoot-movement

\subsubsection{Second Project: Homes for the Homeless}

Homes for the Homeless was a natural extension of the college's goal of providing services to the poor. Inhabited mainly by labourers and farmers, they were quite suitable for them because of their low cost. They are flat-roofed houses that consist of two rooms and a toilet within a rectangular or L-shaped block. Walled courtyards around some of the houses offer outdoor space for household activities. Some homes differ from this model and have been modified to suit the basic needs and resources of their users. Earth-brick was the constructing material for most of the buildings but people with greater economic resources have used other materials including rubble stone and lime mortar. The houses have proven themselves to be extremely functional and far better than the ones that their occupants used to live in. [15]

\subsubsection{Third Project: Rainwater Harvesting}

Large-scale efforts to provide water in rural areas are typically made by drilling to search for subterranean water sources. This is an expensive, short term process and often yields "brackish water, unfit for human consumption”.

"The rainwater-harvesting structures were based on the college's belief that tried-and-tested technologies used by the people for several hundred years to provide safe drinking water should be respected and applied on a large scale.” Rainwater is thus collected from the flat rooftops and channeled to water storage tanks, usually situated underground. In an arid region such as Tilonia, sufficient water supply and adequate storage are crucial to the survival of the community.

"The new system is inexpensive and provides a yearround water supply, even when the monsoon rainfall is low, thus safe-guarding emergency needs.” One of the main benefits of this system is the improvement of girls' attendance in several rural primary schools because they do not have to spend hours walking several kilometers to bring clean drinking water. Another great benefit of the system is wasteland reclamation. [15]

\subsection{Awards and Achievements}

Barefoot College is the only College in India built by the poor and managed by the rural poor who earn less than \$1/day. Almost the only College left in India that respects and practices the work style and life style of Mahatma Gandhi. It is a College where the teacher is the learner and the learner the teacher. It is the only College in India where traditional knowledge and practical skills of the poor are given more importance and priority than paper degrees or qualifications. For all of the previous, it was rewarded the following rewards:

- In 1998 the College was awarded the Indira Gandhi Paryavaran Puraskar (Indira Gandhi Environment Award), by the Ministry of Environment and Forests, Government of India.

- In 2003 the Barefoot College won an Ashden Award for sustainable energy for its work bringing solar power to rural villages. [16]

- Roy, founder of the College, received the 7th annual Clinton Global Citizen Awards, 2013. The Clinton Global Citizen Awards were launched in 2007 to honor outstanding individuals for their visionary leadership and demonstrated impact of their work in solving global issues. [17]

- The creators of the campus near Tilonia received the Aga Khan Award for Architecture.

- Roy has been named by The Guardian one of the 50 environmentalists who could save the planet.

- Barefoot College has been ranked as one of the Top NGOs in the world by The Global Journal in the 2013. [18]

This way the College is classified as an NGO and not as a college or university in spite of these awards and 
international recognition of its achievements concerning its role in society. This is because it is not considered as formal education!!

\section{Conclusion}

Through presenting the educational model of Barefoot College it is concluded that there are several positive aspects that we should pay attention to and use what would be beneficial about it. There are also some negative aspects that we should take notice of and study in order to avoid them and prevent similar things from happening should we try to apply this model.

Regarding the positive aspects that have been observed are as follows:

- Being an outstanding architect requires that the person should have natural inclination, creativity and information about the principles of construction and does not require only having specific grades in General Secondary Education Degree (Thanaweya Amma) -or any of its equivalents.

- The example of this college proves this premise to be right. The illiterate architect who built the Barefoot College campus won the Aga Khan Award for Architecture whereas many of the graduates of regular faculties of Architecture could not.

- The right application of the concept and outcome of education, for the aim of the whole process of education is not obtaining a paper degree but its true reward is the impact of an illiterate woman that becomes a solar energy engineer or a man that becomes an architect. This is what the college system emphasizes and it shows starting with the admission of students as the founder Bunker Roy explains saying: "the first thing we did was to disqualify anyone with a paper degree.” Therefore, all prerequisites for admission were cancelled including speaking the language.

- This was further confirmed by training members of the rural community to be teachers in local schools. The objective is to decrease their dependency on external aid as well as to reduce migration by generating employment within the rural communities. Besides, the urban experts with paper degrees do not have the patience and cannot respect the traditional knowledge; these qualities make them unfit to live and work in remote areas.

- Practical learning is fundamental in the formation of an outstanding architect. The most remarkable feature that the "Barefoot architects" have is the practical experience that they earned through practicing construction, the components of which were passed from one generation to another. It has been demonstrated that experience involving active participation along with regular repetition help trainees. "Learning by doing" is the best way of learning.

- Absolute freedom of thinking as everyone whether a teacher or a learner- should be openminded towards trying new ideas, even crazy ones, and accepting them. This is what leads to creativity which is the base of architectural work.

- Combining traditional knowledge, simple skills and inherited architectural traditions. One of the conditions of the evolution of the profession is to stay connected to its origins and, at the same time, not to neglect all that is modern given that it is useful.

- The interchanging roles of teachers and learners. They both teach and learn and the relationship between them is not authoritarian but democratic. This was obvious since the very beginning in the late 60's when a small group of educated young people started seeking alternative ways of dealing with poverty in the Indian countryside.

- Later on, the educational policy of the College was the relationship of equality and respect between a specialist and the rural people.

- Student's participation in the planning and decision-making process. A group of rural men and women known as 'Barefoot Professionals' plan and carry out all initiatives whether social, political or economic. This network consists of the students and teachers in the College.

- We would also like to emphasize the College's six fundamental positive values which are: " 1 . Austerity, 2. Equality, 3. Collective DecisionMaking, 4. Decentralization, 5. Self-Evaluation, 6. Transparency and Accountability."

- There are no leaders or superiors. This way of problem-solving and decision-making is democratic and decentralized. This represents one of the most important conditions for creativity.

- Applying a Gandhian bottom-up principle in education which states that the most appropriate solutions always come from the base -represented by the students in this case- then they are ascended to be implemented.

\section{Concerning the negative aspects:}

- The College has recently converted to the "self- 
help" system that Hassan Fathy mentioned in his book Architecture for the poor. The concept could be summarized as follows: the government, the United Nations or any other supervising entity provides the peasants in any rural place that suffers from recession with equipment and materials to build their own houses.

- The peasants work for free and, with the help of the equipment and materials given to them, they improve their condition. The problem with this system is that the community becomes dependent on the external aid which does not last forever.

- Peasants learn how to operate a concrete mixer or how to install a prefabricated roof but as soon as the supply of materials stop they return to their initial state - a really deteriorated one- with the obvious exception of the buildings they already gained possession of.

- The point is that they can't make use of the skills they learned because they can't afford buying the equipment or materials and this endangers the whole approach.

\section{Results and recommendations}

Scientific research should focus more on solving the problems of poor areas and to spread such models that solve problems before they appear through:

- Increasing scientific research in this field.

- Benefitting from previous studies both local Hassan Fathy's architecture for the poor- and international like the Indian model we have discussed.

- Giving more attention to this on a larger scale so it would be carried out on a state level by research groups in universities and not leave it to individual efforts because solving the society's problems is a fundamental role of universities.

- Trying to practically implement these models in the poor areas in Egypt and observing the experience along all its steps in a scientific way to correct its course if needed.

Finally, we should emphasize that the main goal of Science is to find solutions to the society's problems as it is of constructing universities and conferring degrees to students.

\section{References}

[1] Jolan van Lengen, “The Barefoot Architect”, Introduction, October 2007. Available from:

https://www.amazon.com/Barefoot-Architect-Johan-vanLengen/dp/0936070420

[2] http://www.barefootcollege.org/about/

[3] http://www.barefootcollege.org/barefoot-approach/

[4] https://en.wikipedia.org/wiki/Barefoot_College

[5] http://www.barefootcollege.org/disrupting-poverty-howbarefoot-college-is-empowering-women/

[6] Barefoot Architects: Tilonia, India. In Modernity and Community: Architecture in the Islamic World (book) p.78. Thames \& Hudson and the Aga Khan Award for Architecture. Correa, Charles, Kenneth Frampton \& David Robson, eds. 2001. ArchNet digital library.

[7] http://www.imow.org/economica/stories/viewStory?storyid=4 525

[8] http://www.barefootcollege.org/women-barefoot-solarengineers-a-community-solution/

[9] http://www.barefootcollege.org/the-worlds-only-college-forthe-rural-poor-channeling-gandhi-creating-21st-centurysolutions/

[10] Hassan Fathy, “Architecture for the Poor”, p. xii, University of Chicago press, United States, December 2000.

[11] Barefoot Architects: Tilonia, India. In Modernity and Community: Architecture in the Islamic World (book) p.79. Thames \& Hudson and the Aga Khan Award for Architecture. Correa, Charles, Kenneth Frampton \& David Robson, eds. 2001. ArchNet digital library.

[12] http://www.barefootcollege.org/barefoot-approach/campuslife/

[13] Barefoot Architects: Tilonia, India. In Modernity and Community: Architecture in the Islamic World (book) pp.7980. Thames \& Hudson and the Aga Khan Award for Architecture. Correa, Charles, Kenneth Frampton \& David Robson, eds. 2001. ArchNet digital library.

[14] https://www.betterplace.org/en/organisations/barefootcollegei ndia

[15] Barefoot Architects: Tilonia, India. In Modernity and Community: Architecture in the Islamic World (book) p.80. Thames \& Hudson and the Aga Khan Award for Architecture. Correa, Charles, Kenneth Frampton \& David Robson, eds. 2001. ArchNet digital library.

[16] https://en.wikipedia.org/wiki/Barefoot_College

[17] http://www.barefootcollege.org/president-clinton-announcesrecipients-of-7th-annual-clinton-global-citizen-awards/

[18] http://www.barefootcollege.org/barefoot-college-selected-inthe-top-100-ngos-in-the-world-2-years-in-a-row/

[19] Sanjit "Bunker" Roy (born 2 August 1945) is an Indian social activist and educator who founded the Barefoot College. He was selected as one of Time 100's 100 most influential personalities in 2010 for his work in educating illiterate and semi-literate rural Indians. https://en.wikipedia.org/wiki/Bunker_Roy

[20] Hassan Fathy (1900-1989) was a noted Egyptian architect who pioneered appropriate technology for building in Egypt, especially by working to reestablish the use of adobe and traditional as opposed to western building designs and layouts. Fathy was recognized with the Aga Khan Chairman's Award for Architecture in 1980. In 2017, Google celebrated Fathy with a Google Doodle for "pioneering new methods [in architecture], respecting tradition, and valuing all walks of life. https://en.wikipedia.org/wiki/Hassan_Fathy 